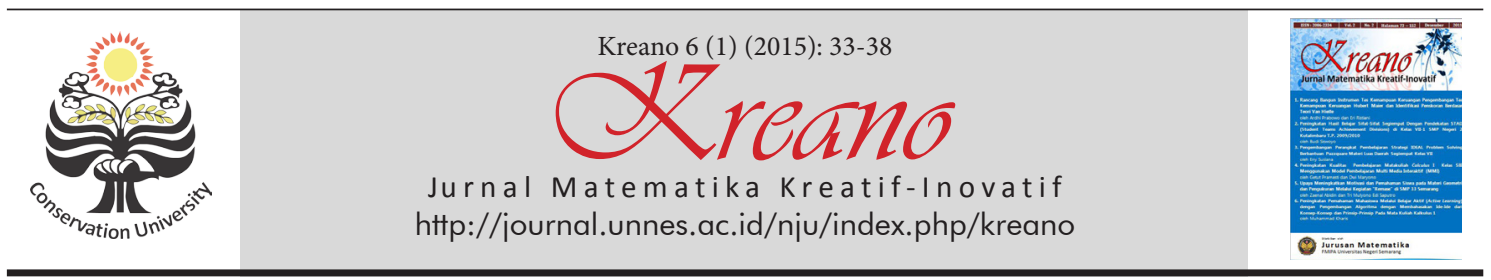

\title{
Media Pembelajaran Geometri Menggunakan Pendekatan Pendidikan Matematika Realistik Berbasis GeoGebra
}

\author{
Bagus Ardi Saputro', Muhammad Prayito', dan Farida Nursyahidah' \\ 'Jurusan Pendidikan Matematika FMIPATI Universitas PGRI Semarang \\ Email: 1bagusardisaputro@yahoo.co.id
}

DOI: http://dx.doi.org/10.15294/kreano.v6i1.4471

Received : August 2015; Accepted: September 2015; Published: September 2015

\begin{abstract}
Abstrak
Tujuan dari penelitian ini adalah untuk mengembangkan media geometri menggunakan pendekatan Pendidikan Matematika Realistik Indonesia (PMRI) berbasis GeoGebra. Metode yang digunakan adalah Research and Development (R\&D) dengan model 4D Thiagarajan yang terdiri dari tahap pendefinisian, perancangan, pengembangan, dan diseminasi. Hasil penelitian ini menunjukkan bahwa hasil validasi media dari validator 1 mendapat skor 46 atau dalam nilai sangat baik, dan dari validator 2 mendapat skor 45 atau dalam nilai baik. Sedangkan hasil validasi materi dari kedua validator manyatakan bahwa media yang dikembangkan ini sangat baik dengan skor masing-masing 51 dan 50. Media ini dapat menciptakan proses pembelajaran yang berpusat pada siswa, mengeksplorasi khasanah kearifan lokal yang digunakan sebagai konteks pembelajaran yang memenuhi semua karakteristik PMRI dan berbasis GeoGebra.
\end{abstract}

\begin{abstract}
The aim of this research is to develop geometry media using PMRI approach based on GeoGebra. This research used methodology of research and development $(R \& D)$ of four model of Thiagarajan that consist of four step, which are define, design, develop, and disseminate. The result of this research shows that validate of media from the first expert reviewer got score 46 or in other word this media is very good, then score from the second expert reviewer got 45 or in other word this media is good. And the result of validate of material from both expert reviewer is very good by getting score 51 and 50 respectively. The using of this media can create learning process with students center, explore the local wisdom as a context in learning that material that fulfill all of the characteristic of PMRI based on GeoGebra.
\end{abstract}

Keywords: Learning Media; PMRI; GeoGebra

\section{PENDAHULUAN}

Kurikulum 2013 merupakan jawaban tentang beberapa permasalahan pendidikan matematika di Indonesia. Salah satu permasalahan dalam pembelajaran matematika diungkap oleh Programme for International Student Assessment (PISA) 2000/2001. Hasil survey PISA menunjukkan bahwa siswa lemah dalam geometri, khususnya dalam pemahaman ruang dan bentuk (Suwaji, 2008). Pertanyaan yang sering muncul adalah mengapa orang sulit belajar geometri? Pertanyaan ini dijawab oleh Schwartz, J.E. (2014) dalam artikelnya yang menyatakan bahwa proses belajar geometri harus disesuaikan dengan level belajar Van
Hiele.

Selanjutnya, Hohenwarter dan Judith Preiner (2007) menawarkan software pendidikan matematika yang gratis yaitu GeoGebra. Dikatakan bahwa GeoGebra memang khusus dirancang untuk tujuan pendidikan. GeoGebra dapat membantu siswa untuk mengembangkan proses eksperimen, berorientasi pada masalah, dan pembelajaran penemuan pada konsep-konsep matematika. Hal ini sangat relevan dengan aspek pengetahuan terkait menganalisis dan mengevaluasi serta aspek keterampilan seperti mencoba, menalar, menyaji dan mencipta sehingga siswa akan sampai pada aspek menghayati dan menga- 
malkan. Oleh sebab itu, GeoGebra sangat sesuai dengan persepsi Kurikulum 2013.

Kurikulum 2013 memberikan pedoman tentang proses pembelajaran, seperti pada kegiatan pembelajaran diharapkan menggunakan pendekatan tematik, tematik terpadu, saintifik, inkuiri dan penemuan kembali berbasis pemecahan masalah. Dari berbagai pendekatan yang berkembang, pendekatan realistic mathematic education atau biasa dikenal dengan istilah Pendidikan Matematika Realistik Indonesia (PMRI). Gravemeijer (1994) menyebutkan karakteristik PMRI ada lima, diantaranya adalah (1) menggunakan masalah kontekstual, (2) menggunakan model, (3) menggunakan kontribusi siswa, (4) terjadinya interaktivitas, dan (5) terintegrasi dengan topik pembelajaran lainnya. Oleh karena itu, PMRI merupakan salah satu pendekatan yang tepat untuk digunakan.

Banyak penelitian yang telah dilakukan untuk menguji, mendalami dan mengembangkan penggunaan pendekatan ini dalam pembelajaran. Seperti hasil penelitian Tandiling. E (2010) yang telah melakukan penelitian implementasi realistic matematics education di sekolah. Senada dengan hal tersebut, Nursyahidah (2013) juga telah melakukan penelitian tentang pembelajaran matematika menggunakan pendekatan PMRI, diperoleh hasil bahwa proses pembelajaran matematika menjadi lebih bermakna, menyenangkan, dan meningkatkan pemahaman konsep yang sedang dipelajari. Sehingga pendekatan PMRI sangat efektif digunakan dalam pembelajaran matematika di kelas.

Berdasarkan latar belakang tersebut, perlu dikembangkan sebuah media pembelajaran yang mampu menjawab masalah dalam pembelajaran matematika khususnya geometri dengan menggunakan pendekatan PMRI yang berbasis software GeoGebra. Media tersebut diharapkan mampu membawa siswa menguasai teknologi dan tetap tidak melupakan khasanah kearifan lokal yang dapat dijadikan sebagai konteks dalam pembelajaran matematika.

\section{METODE}

Metode yang digunakan dalam penelitian ini adalah Research and Development (R\&D).
Tahap-tahap yang dilaksanakan dalam penelitian ini adalah mengacu pada model $4 \mathrm{D}$ Thiagarajan yang meliputi perencanaan, perancangan, pengembangan, dan diseminasi. Adapun dalam artikel ini hanya akan dibahas mengenai tahap pengembangan. Subjek yang dilibatkan dalam penelitian ini adalah siswa kelas VIIC SMP Negeri 29 Semarang, Jawa Tengah, Indonesia.

\section{HASIL DAN PEMBAHASAN}

Berdasarkan penelitian yang telah dilakukan, dapat diperoleh hasil validasi dari dua orang validator. Validasi yang dilakukan meliputi validasi media dan validasi materi. Hasil dari validasi ini dapat menjelaskan kualitas media yang dikembangkan dan selanjutnya mengenai pengembangan media tersebut dapat dijelaskan sebagai berikut.

\section{Hasil Validasi Media dan Validasi Materi}

Hasil validasi media dari kedua validator diperoleh skor dari validator 1 yaitu 46 yang memberikan nilai sangat baik, artinya kategori media sangat baik, sehingga dapat digunakan tanpa revisi. Sedangkan dari validator 2 memberikan skor 45 dengan nilai baik, artinya kategori media baik, sehingga dapat dipakai dengan sedikit revisi.

Selanjutnya berdasarkan validasi materi dari kedua validator diperoleh skor dari validator 1 dan validator 2 berturut-turut yaitu 51 dan 50 yang memberikan nilai sangat baik, artinya kategori materi sangat baik, sehingga dapat digunakan tanpa revisi.

Adapun komentar secara keseluruhan terkait materi dapat dibedakan menjadi beberapa hal. Mengenai proses pembelajaran menggunakan media yang dikembangkan, yaitu pembelajaran yang disajikan menekankan pada keterampilan proses dan berpusat pada peserta didik. Terkait penggunaan konteks pada pembelajaran dengan pendekatan PMRI, konteks yang disajikan cukup menarik dan sesuai dengan pengetahuan awal siswa serta familiar di pikiran siswa. Selanjutnya terkait konsep yang disampaikan, yaitu konsep yang diberikan juga runtut dan sistematis. Namun, perlu diperhatikan kedalaman materi 
yang ada pada media yang disajikan.

Setelah media yang dikembangkan tersebut divalidasi oleh para validator kemudian dilakukan sedikit revisi sesuai dengan saran yang diberikan sebelum diujicobakan di kelas pada proses pembelajaran.

\section{Pengembangan Media dengan} Pendekatan PMRI Berbasis GeoGebra Media ini dikembangkan menggunakan pendekatan PMRI. Adapun beberapa karakeristik dalam PMRI sudah disajikan dengan baik pada media yang dikembangkan. Karakteristik yang pertama yaitu use of context, atau dapat dikatakan menggunakan konteks yang sudah familiar di lingkungan siswa sehingga dapat dijadikan sebagai jembatan untuk mempelajari materi yang disajikan. Ada beberapa konteks yang digunakan dalam pemgembangan media ini, diantaranya penggunaan wayang kulit Bima yang merupakan budaya jawa dan familiar di kalangan siswa. Wayang kulit Bima tersebut dimodifikasi dengan GeoGebra sehingga tangannya dapat bergerak-gerak untuk menunjukkan jenis-jenis sudut. Adapun penggunaan konteks berupa wayang kulit Bima dalam GeoGebra dapat ditunjukkan pada gambar 1 berikut.

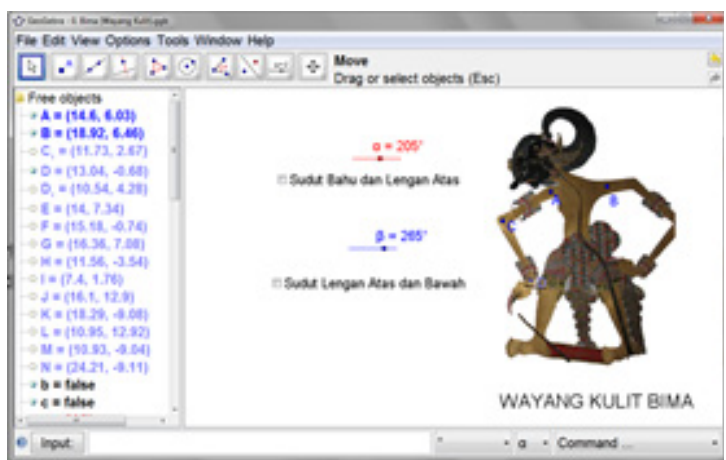

Gambar 1. Penggunaan Wayang Kulit Bima sebagai konteks dalam GeoGebra

Selanjutnya penggunaan jam juga untuk menunjukkan jenis-jenis sudut. Jam yang dimodifikasi menggunakan GeoGebra dapat mempermudah siswa menentukan sudut yang dibentuk antara jarum panjang dan jarum pendek. Dengan menggunakan GeoGebra penentuan sudut menjadi lebih mudah dan menyenangkan. Untuk menentukan besar sudut yang dibentuk pada pukul berapa lebih berapa menit hanya tinggal menggeser tombol jam dan menit yang tersedia selanjutnya besar sudut lancip maupun sudut reflek yang terbentuk dapat diketahui. Adapun penggunaan konteks jam yang dikembangkan dengan GeoGebra dapat dilihat pada gambar 2 sebagai berikut.

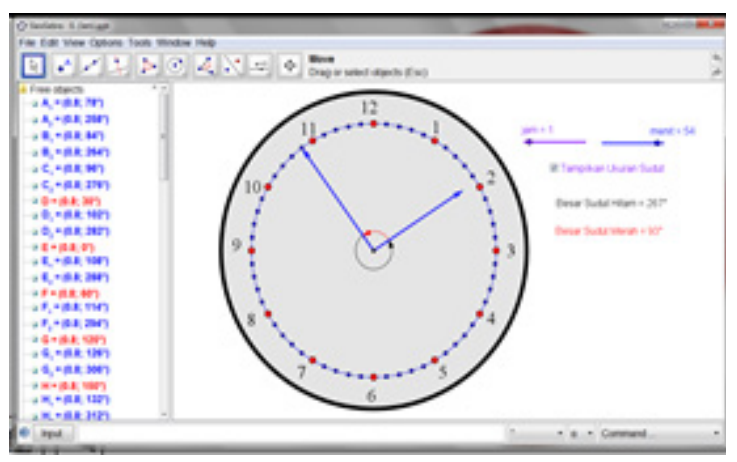

Gambar 2. Penggunaan Jam Sebagai Konteks Dalam GeoGebra

Kedua konteks tersebut digunakan untuk mempelajari jenis-jenis sudut. Selanjutnya untuk mempelajari hubungan antar sudut digunakan beberapa konteks yang relevan. Diantaranya penggunaan konteks pigura untuk mempelajari hubungan sudut berpenyiku. Yang selanjutnya dieksplorasi menggunakan GeoGebra. Konteks pigura dan tampilan GeoGebra untuk mempelajari sudut berpenyiku ditunjukkan pada gambar 3 dan 4 berikut.

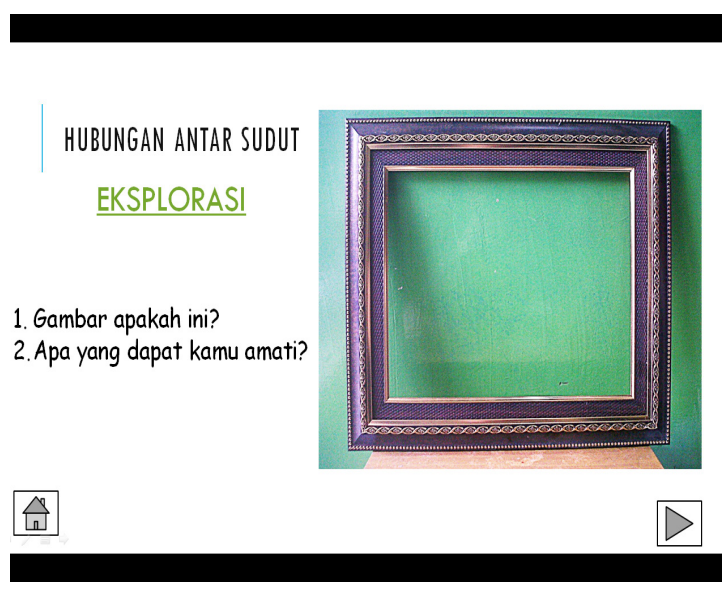

Gambar 3. Konteks Pigura Untuk Sudut Berpenyiku

Dalam media di gambar 4 tersebut, ukuran sudut dapat diubah-ubah sesuai keinginan dan siswa dapat diminta untuk menentukan besar sudut penyiku dari sudut lainnya. Selain itu siswa juga dapat diajak bernalar 
mengetahui buhungan dua sudut yang saling berpenyiku. Siswa dapat mengetahui bahwa jika ada dua sudut berapapun besarnya jika dijumahkan menghasilkan $90^{\circ}$ berarti kedua sudut tersebut saling berpenyiku.

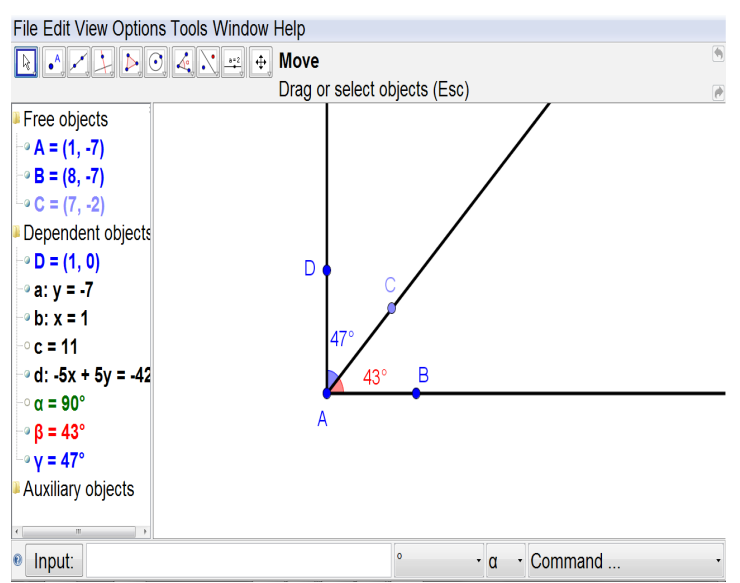

Gambar 4. Penyajian GeoGebra Untuk Sudut Berpenyiku

Selanjutnya hubungan sudut berpelurus. Konteks yang digunakan dalam belajar materi ini adalah kerangka atap rumah yang membentuk sudut saling berpelurus. Dan selanjutnya dapat dieksplorasi menggunakan GeoGebra. Konteks dan penyajian dalam GeoGebra dapat ditunjukkan pada gambar 5 dan 6 berikut.

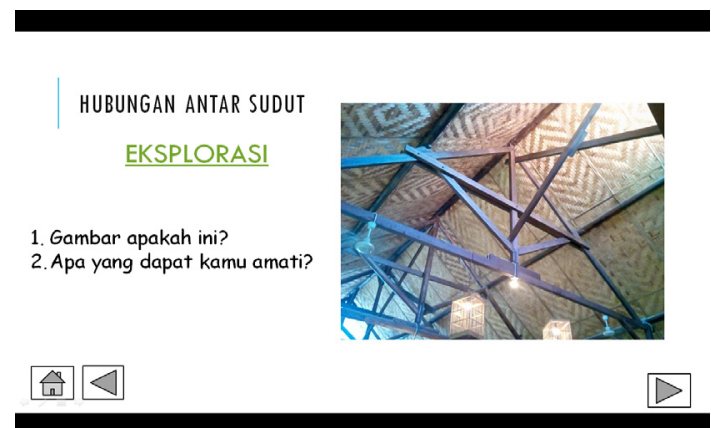

Gambar 5. Konteks Kerangka Atap Rumah Untuk Sudut Berpelurus

Dalam media gambar 6 tersebut, ukuran sudut dapat diubah-ubah sesuai keinginan dan siswa dapat diminta untuk menentukan besar sudut pelurus dari sudut lainnya. Selain itu siswa juga dapat diajak bernalar mengetahui buhungan dua sudut yang saling berpelurus. Siswa dapat mengetahui bahwa jika ada dua sudut berapapun besarnya jika dijumah- kan menghasilkan $180^{\circ}$ berarti kedua sudut tersebut saling berpelurus.

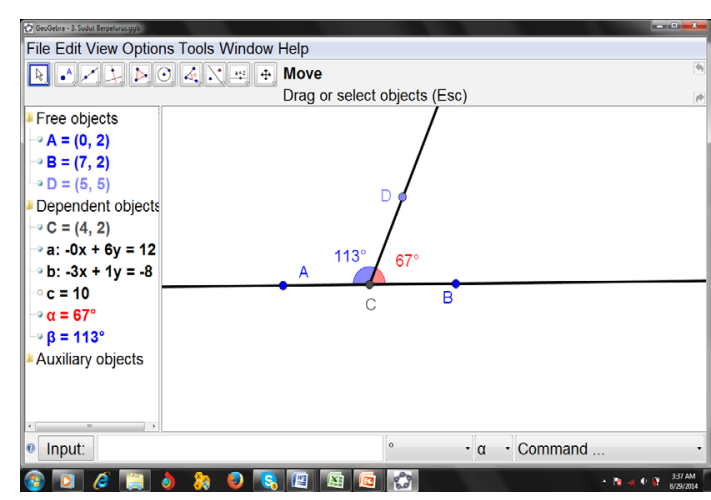

Gambar 6. Penyajian GeoGebra untuk Sudut Berpelurus

Selanjutnya hubungan sudut bertolak belakang. Konteks yang digunakan dalam belajar materi ini adalah kerangka atap rumah yang membentuk sudut saling bertolak belakang. Kemudian dapat dieksplorasi menggunakan GeoGebra. Konteks dan penyajian dalam GeoGebra dapat ditunjukkan pada gambar 7 dan 8 berikut.

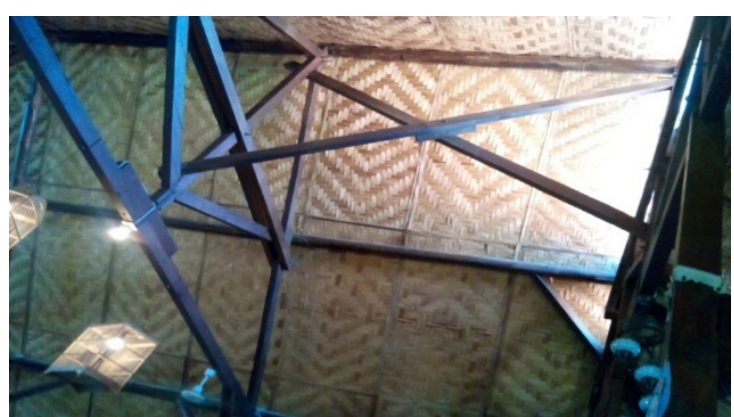

Gambar 7. Konteks Kerangka Atap Rumah Untuk Sudut Bertolak Belakang

Dalam media gambar 8 tersebut, ukuran sudut dapat diubah-ubah sesuai keinginan dan siswa dapat diminta untuk menentukan besar sudut bertolak belakang dari sudut lainnya. Selain itu siswa juga dapat diajak bernalar mengetahui buhungan dua sudut yang saling bertolak belakang. Siswa dapat mengetahui bahwa jika ada dua sudut yang letaknya saling membelakangi satu sama lain dan besarnya sama berarti kedua sudut tersebut bertolak belakang. Selain itu, dari sudut bertolak belakang ini juga dapat ditemukan hubungan sudut yang lain yaitu saling berpelurus. Dengan menggunakan media ini siswa diarahkan un- 
tuk dapat menemukan hubungan-hubungan sudut yang terbentuk.

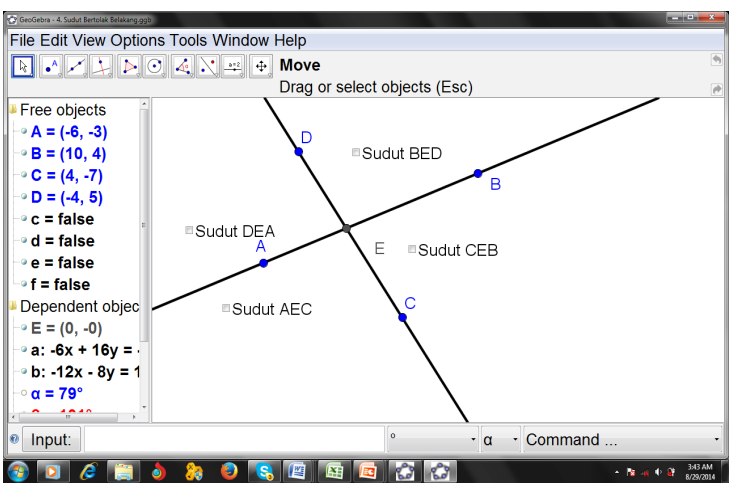

Gambar 8. Penyajian GeoGebra Untuk Sudut Bertolak Belakang

Selanjutnya dalam media tersebut dibahas sudut-sudut yang terbentuk dalam dua garis sejajar yang dipotong oleh garis transversal. Konteks yang digunakan dalam belajar materi ini adalah rel kereta api dan bangunan paragon, salah satu mall di semarang yang sudah familiar di kehidupan sehari-hari siswa. Yang selanjutnya dapat dieksplorasi menggunakan GeoGebra. Konteks dan penyajian dalam GeoGebra dapat ditunjukkan pada gambar 9 dan 10.

Dari media tersebut, ukuran sudut dapat diubah-ubah sesuai keinginan dan siswa dapat diminta untuk menentukan besar masing-masing sudut yang terbentuk jika salah satu sudut diketahui. Selain itu siswa juga dapat diajak bernalar untuk mengetahui hubungan dua sudut yang saling bertolak belakang maupun berpelurus yang ada pada dua garis sejajar yang dipotong oleh garis transversal.

Selain itu siswa dapat mengetahui istilah baru dari sudut-susut yang terbentuk dan sifat ukuran sudut. Antara lain, jika sudut tersebut menghadap arah yang sama, maka disebut sudut sehadap dan mempunyai besar ukuran yang sama. Sudut yang letaknya di dalam sudut yang saling sejajar tersebut disebut sebagai sudut dalam. Berdasarkan letaknya lagi sudut dalam tersebut dibagi menjadi sudut dalam sepihak jika letaknya di dalam dan dalam pihak yang sama. Sedangkan sudut dalam berseberangan jika letaknya saling berseberangan dan berada di dalam. Siswa juga dapat mengetahui istilah sudut yang berada di luar garis sejajar sebagai sudut luar. Seperti halnya sudut dalam, sudut luar juga ada sudut luar sepihak dan sudut luar berseberangan. Dengan sifat ukuran sudut dapat diketahui menggunakan hubungan sudut yang meraka pelajari sebelumnya.

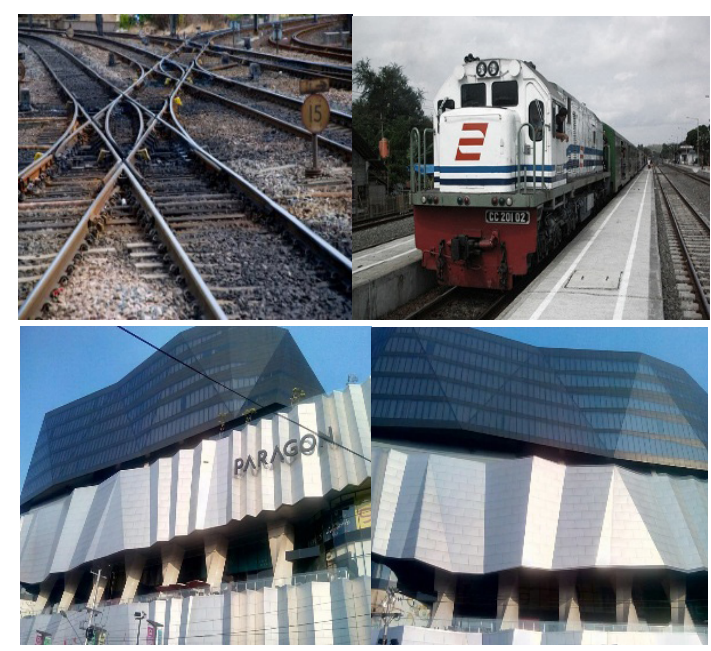

Gambar 9. Konteks Rel Kereta Api dan Bangunan Paragon

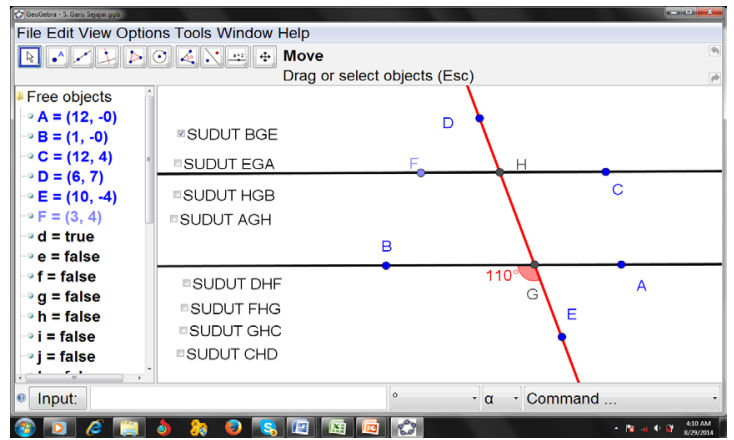

Gambar 10. Penyajian GeoGebra Untuk SudutSudut Pada Garis Sejajar

Dengan menggunakan konteks dan selanjutnya dilakukan eksplorasi menggunakan GeoGebra konsep yang diajarkan dapat dipahami siswa dengan baik. Selanjutnya, karakteristik PMRI yang kedua adalah penggunaan model. Dalam pengembagan media ini juga memuat model yang dapat digambarkan siswa. Mulai dari konteks berupa kerangka atap, mereka memodelkan menjadi garis yang dpat membentuk sudut yang dapat dieksplorasi untuk tingkat pemahaman terhadap materi selajutnya.

Karakteristik yang ketiga yaitu adanya kontribusi siswa. Dengan menggunakan media yang dikembangkan, pembelajaran dapat berpusat pada siswa. Siswa dibentuk kelom- 
pok untuk mendiskusikan masalah pada Lembar Aktivitas Siswa (LAS) yang berasal dari media yang dikembangkan. Siswa menjadi lebih aktif mengemukakan pendapat di dalam kelompok dan menuangkan gagasannya pada LAS tersebut.

Selanjutnya, karakteristik keempat adalah interaktivitas. Siswa yang sudah berdiskusi mengemukakan pendapatnya dalam kelompoknya dan menuangkan ke dalam LAS kemudian diminta untuk mempresentasikan hasil diskusi kelompoknya ke depan kelas. Meraka sekarang berdiskusi secara klasikal dengan dipandu guru. Adanya diskusi antara siswa dengan siswa maupun siswa dengan guru untuk menyatukan pendapat mengenai materi yang dipelajari. Bagi siswa yang mempunyai pendapat berbeda diberi kesempatan untuk mengemukakan pendapatnya, hingga akhirnya jika ada yang masih salah dalam menjawab mereka dapat menemukan sendiri pemahaman yang benar.

Karakteristik PMRI yang kelima adalah terintegrasi dengan topik pembelajaran lainnya. Dalam pemilihan konteks untuk pembelajaran garis dan sudut ini dipilih wayang, sehingga dapat dikaitkan dengan mata pelajaran sejarah maupun PKn tentang sikap sopan santun. Kemudian pemiliha konteks kereta dapat dikaitkan dengan mata pelajaran fisika tentang kecepatan. Dan konteks kerangka atap rumah dan paragon dapat dikaitkan dengan mata pelajaran seni rupa dalam merancang bangunan, perpaduan seni dan hitung matematis.
Berdasarkan pembahasan tesebut, media yang dikembangkan sudah memuat semua karakteristik PMRI dan Berbasis GeoGebra. Media tersebut dapat dikatakan valid karena sesuai dengan penggunaan dan praktis karena dapat dengan mudah digunakan.

\section{SIMPULAN}

Kesimpulan yang diperoleh dari penelitian ini adalah dihasilkan media pembelajaran geometri SMP dengan pendekatan PMRI berbasis GeoGebra yang dalam kategori sangat baik untuk digunakan dalam pembelajaran. Penggunaan konteks yang bervariasi yang dikolaborasikan dengan software GeoGebra dapat memberikan siswa hal-hal baru sehingga siswa lebih aktif dalam belajar yang menyenangkan.

\section{DAFTAR PUSTAKA}

Gravemeijer, K. (1994). Developing Realistic Mathematics Education. Utrecht: Technipress, Culemborg.

Hohenwarter, M dan Preiner. (2007). Dinamic Mathemtics with GeoGebra. Journal of Online mathematics and its Apllication. Mathematical Association of America. Online di http://www.maa.org/ publications

Nursyahidah, F. (2013). Supporting First Grade Students' Understanding of Addition up to 20 Using Traditional Game. IndoMS. J.M.E. 4(2). 212-223.

Schwartz, J.E. (2014). Why People Difficuly Geometry? Online di http://www.education.com.

Suwaji, U.T. (2008). Permasalahan Pembelajaran Geometri Ruang SMP. P4TK Matematika Yogyakarta. Alamat: http://p4tkmatematika.org.

Tandiling, E. (2010). Implementasi Realistics Mathematics Education di Sekolah. Jurnal Guru Membangun, 25(3) 